\title{
CASTING DALITS IN THE HINDU FOLD: GANDHI, HARIJAN SEVAK SANGH AND THE TEMPLE MOVEMENT IN COLONIAL INDIA
}

\author{
VAISHALI \\ Ph.D. Scholar, Department of History, University of Delhi, New Delhi, India
}

This paper aims to decode the origin and hypocritic gestures of Gandhi's Harijan and temple entry movements that aim to patronize the Dalit community, to keep them within the Hindu fold and thereby earn their support in various activities of the Indian national movement for freedom.
\end{abstract}

KEYWORDS: Harijan Movement, Gandhi, Dalit \& Temple

Received: Jun 01, 2021; Accepted: Jun 20, 2021; Published: Jun 31, 2021; Paper Id.: IJHRDEC20213

\section{INTRODUCTION}

Harijan movement and the temple movement under the banner of the Harijan movement were the two crucial movements initiated by Gandhi to full fill his verdicts of eradication of untouchability made during the signing of the Poona Pact. Gandhi wrongly perceived Ambedkar's proposal of a separate electorate as another hammer to national unity, inspired by the British policy of divide and rule. Against the proposal, he went on hunger strike, and consequently, Poona Pact was signed between him and Ambedkar. Poona Pact discarded the idea of "separate electorates" for untouchables, however in order to influence Ambedkar and earn the loyalty of untouchables he promised to work for the upliftment of Dalits and eradicate untouchability from Hindu society. Therefore, the Harijan movement was a social movement that intended to purify Hinduism, which led to some important political ramifications in the medium and long term. Through this movement, Gandhi called for the atonement of sins by upper-caste Hindus for the historical injustice to Dalits. He tours all over India to influence, mobilize and earn support for his Harijan movement. He emphasized on the need to improve the condition of untouchables in society through various programs such as education, cleanliness, hygiene, giving up beef-eating and giving up alcohol consumption, allowing them temple entry, etc. Gandhi opinion that such movement would pave the way for the unification of all Indians. But his movement was criticised as Gandhi did not debunk the caste system, upon which the entire concept of untouchability relaying. He did not follow a coherent and compelling strategy but was criticised for his hypocritic and patronising gesture towards Dalits. Also, he ignored have a concrete solution to the question of the economic upliftment of Dalits.

The nationalist historiography in India recognized Indian National Congress as the only body representing the national interests of all in colonial India. But historians belong to different schools of thought denounce such an approach. They emphasized that any initiative from the side of the colonial government to give concessions to any group other than the elite Upper Caste was often labelled as 'divide and rule policy.' Muslims, Sikhs, Dalits, or Adivasis asking for their representation were often labelled selfish, non-patriotic, and British agents. In the language of 'Nation' and 'Nationalism,' interests of those living at the margins of society were hardly noticed. 
Their grievances were either silenced or suppressed. Till the 1920s, the Indian National Congress was primarily recognized as a party of the educated elite class. Things began to change when Gandhi comes to play a central role in the Indian national movement and transformed the freedom struggle into a mass movement. ${ }^{1}$ However, still, the leadership majorly rested within the hands of foreign-educated Upper Caste elites with the negligible representation of peasants, lower castes, and other backward identities. To keep the nation's interests intact, they intentionally 'overlooked 'trivial' issues of caste, creed, race, and language. One should question why until the second Round Table Conference or Macdonald's communal award in 1932, Congress and Gandhi did not take the matter of untouchability and Dalit upliftment seriously. Even when different agencies like Christian missionaries, Arya Samaj, Brahmo Samaj, leaders of, philanthropic societies, political parties, and Government all were giving their sympathy and endeavors to Dalit, lead the birth of anti-caste movements, Sudhi movement, Self-respect movement, Adh-dharm, Adi- Hindu movement active since the 1920s itself. What makes the Harijan Movement the youngest member in this various agency or list? Before discussing the movement, one should analyze the circumstance and the perspective with which the movement was started.

\section{BACKGROUND AND REASON BEHIND COMMUNAL PACT AND HARIJAN MOVEMENT}

The Morley-Minto Reforms, 1909 was the first time the colonial government came up with special provisions for individuals belonging to religious minority communities, albeit the untouchables remained largely ignored. The Congress criticized the Britishers for causing fragmentations within the national movement. Not to mention, until then, the Congress leaders were overlooking grievances and suppressing the demands of Muslims. Moving a step further in the Government of India Act, 1919 recognized the depressed classes as a community with political rights. ${ }^{2}$ Again, the Congress leadership came on the front, oppose, and viewed it as a further attack on 'national integrity'. ${ }^{3}$ It was in this background that the Hindu leadership become so conscious and firmly taking an interest in claiming Dalits as Hindus. It was the same time when Ambedkar also started campaigning for the rights of the untouchables with full enthusiasm. He was representing the Dalit community at every possible opportunity. His emphasis on Dalit political representation became a significant part of almost every petition to the British Government. About thirty-five out of thirty-seven associations were placed before the commission demanded Special Electorates, one favoured Joint Electorates with adult suffrage and reservation of seats, and the other wanted nominations. ${ }^{4}$ In 1924, he formed Bahishkrit Hitkarni Sabha in Bombay to promote education and economic upliftment among the untouchables. Ambedkar started publishing newspapers named Bahishkrit Bharat (1927) Janata (1929) as Dalits elsewhere started organizing themselves under the banners of different organizations. ${ }^{5}$ Untouchables from around the country united behind him on concerns including water access, duties on untouchables, and temple entry. In 1927, he founded Mahad Satyagraha with an objective to access their right to utilise public water. After being touched by Dalits, the tank was later cleaned by orthodox Hindus using ancient rites. The Mahad Satyagraha cannot be seen as a success in terms of obtaining water. However, it can be marked as the first untouchable liberation movement. In 1927 he denounced Brahminism by burning Manusmruti. He got disappointed with the temple movement's outcomes, changed his views, and became more vocal about education and economic opportunities for Dalits. Ambedkar would not accept anything as charity but as a constitutional right as an equal citizen of the nation. In his opinion, achieving 'national interest' would be impossible without including communities living at its margins.

The untouchables were looking at Ambedkar as their sole voice, who has authority at the upper echelons of the power structure. Hundreds of the Chuhras wrote letters in blood to him from Punjab. ${ }^{6}$ He fought for separate electorates for the untouchables at Round Table Conferences and nearly won it for Dalits with such widespread backing. This would 
be a historic movement in the Indian past, as the untouchables would be recognised as a distinct ethnic group from the Hindus. ${ }^{7}$ It's no surprise that Hindu Nationalist leaders in the Congress reacted angrily, calling it an attempt to sabotage "national unity." 'National unity' was disrupted because the Dalits were getting rights similar to the upper caste.

Independence was central to untouchable nationalism, and its embodiment was Ambedkar. His brave fight against Gandhi and the Congress for separate elections was a rallying cry for radical untouchables, and his own untouchables heritage allowed for a sense of pride (that Ambedkar was a Mahar from Bombay Presidency shows how widely the community was defined). From Jalandhar, thousands of Chuhras sent their signatures in blood to London in support of Ambedkar. The AdDharm Mandal and Balmiki Sabha of Jalandhar wanted to send firm proof that Ambedkar spoke the truth when he declared that the Hindu society had cast out untouchables. In order to test the will of the local Hindus, some untouchables took a bucket and a rope and went to the Lal Bazar well. They tried to fill water but were stopped by caste Hindus. The caste Hindus offered to give the untouchables water, but the untouchables wanted to take it themselves. A fight broke out, and the bucket fell into the well. The local newspaper reported the incident. Cuttings of which were sent to Ambedkar as proof of the recalcitrance of Hindus to allow untouchables any dignity. ${ }^{9}$ Mangoo Ram's three-part resolution was passed, pointing that the Ad-Dharm movement will continue, Gandhi should continue his work among the caste Hindus, and that Dr. Ambedkar should be authorised to make any agreement with Gandhi. The inspiration for a struggle governed by the untouchables was sought through Dr. Ambedkar; in 1930, he said that nobody could remove your grievances as well as you can, and you cannot remove them unless you get political power in your own hands. Two years later, these untouchable organizations' positions showed they wanted to assume political power and responsibility. This was Ambedkar's most significant moment, the embodiment of all the men and women who fought so hard to put their telegrams on the table and make them work. When history such as this is made, it is tragic to report its outcome failure. ${ }^{10}$

Gandhi emerged as the saviour of India's upper castes at this time of "crisis." To compel Ambedkar to abandon his demand for separate electorates, Gandhi announced a fast unto death. Gandhi had become India's most influential political leader by this time, and his death would have jeopardised the safety of millions of Dalits. They would have been blamed for his death and faced upper-caste violence. Ambedkar had no choice but to submit to this 'blackmail.' On September 28, 1932, Ambedkar and Gandhi signed the Poona Pact. The demand for separate electorates was formally retracted, and reservation in joint electorates was adopted. Dalits were now viewed as an extension of Hindus, and 'national unity' was created. Gandhi promised to help them and working towards their emancipation. ${ }^{11}$

While Ambedkar saw the caste system as an unjust institution that should be abolished entirely, Gandhi saw it as a divine system that had been tainted by injustice in modern times. ${ }^{12} \mathrm{He}$ established the All-India Anti-Untouchability League, later renamed Harijan Sevak Sangh, under the presidency of Madan Mohan Malaviya, to fulfil the pledge of an attempt to eliminate untouchability made in the Poona Pact. Harijan, a weekly, began to spread the word as well. ${ }^{13}$ The organisation worked to remove the stigma of untouchability from society with the aid of committed workers. ${ }^{14}$ Each volunteer was also required to increase Rs. 1200 a year, with Rs. 30 as his or her monthly allowance. ${ }^{15}$

The Sangh was criticised by Ambedkar for having no untouchables in its ranks. Ambedkar saw it as just a political propaganda tool to secure Dalit support, and he believed that without Dalit representation, no social change could be achieved. Ambedkar desired the complete abolition of the caste system, instead of just removal of untouchability. Dalit issues, in his opinion, also had economic aspects that needed to be resolved as soon as possible. Several Dalits also objected to the use of the word 'Harijan,' for them as it literally meant 'son of Hari,' where Hari is Vishnu's name. As a 
result, they interpreted it as an effort to Hinduize Dalits. It was also stated that children of Devdasis or those whose fathers could not be found were referred to as Harijans. As a result, the phrase was considered derogatory by them. ${ }^{16}$

\section{HARIJAN SEVAK SANGH PROGRAM}

Harijan Sevak Sangh's aim was to gain Dalit confidence and hold them within the folds of both Congress and Hinduism at the same time. "The best propaganda is that of personal example," Gandhi famously told this to Thakkar Bappa. Let every Harijan Sevak lead a model life of purity and simplicity, clothe the Harijan with love, and I am quite sure no counterpropaganda will be necessary". ${ }^{17}$ The harijan movement also emphasized on internal reforms of Dalits, which of course were towards Hinduisation and included vegetarianism. ${ }^{18}$ Rather than recognising Dalits as they were, the movement emphasised that they were in reality "unclean," and that they needed to change themselves. Thereby, the blame of practicing untouchability was shifted from upper castes to the untouchables. ${ }^{19}$ The Dalits were given the task of proving themselves worthy of being considered "touchable." The movement absolved the upper caste of practicing this inhuman practice completely. ${ }^{20}$ Rather than assisting the untouchables in their struggle to rising up the social and economic ladder, Gandhi remains focused on encouraging the upper caste to value Dalits' for the menial services they provided. ${ }^{21}$

In Delhi, Sangh considers that the Chuhras are the most backward among the Dalits. ${ }^{22}$ In Delhi, Bihari Lal founded an ashram in Katwaria Sarai for the education of Dalits, Dr. Sukhdev established the Gandhi Charita hospital in Badarpur, and Prabhu Dayal established a school in Bankner Narela. Congressmen like Jugal Kishore Khanna, Phool Chand Jain, and Dr. Yadhvir Singh toured widely, opened dispensaries, and popularised charkha to mobilise Delhi's rural Dalits. Gandhi visited Dalit houses in Nerala between January 23 and January 25, 1935, during his visit. ${ }^{23}$

\section{TEMPLE MOVEMENT LUNCHED BY SUPPORTERS OF HARIJAN SEVAK SANGH}

When the news of Gandhi's fast reached the Congress workers in Delhi, they called in a meeting at Dayashankar temple, Chandni Chowk regarding the issue of temple entry Dalits. They decided to open the doors of temple for Dalits. Opening ceremony decided was decided on $16^{\text {th }}$ September, 1932 in the presence of Madan Mohan Malviya. ${ }^{24}$ The decision was in line with Gandhi's belief that by joining a Hindu temple, Dalits would experience dignity and brotherhood within Hinduism. ${ }^{25}$ Ambedkar believed otherwise and wanted to ensure first educational, economic and social uplift. He prophesized that Dalits would not be satisfied by just entering the temples. He believes that temple entry would make no substantial difference, and that they would continue to be on the lowest floor of a caste-based society, would compel to live a life that undermines any self-respect they may assert after abolition of so-called untouchability. Ambedkar emphasized that a good deal of propaganda was already carried among people to bring Dalit and upper caste closer. Thereby, a concrete solution to set Dalit economic upliftment was more urgent than temple entry. ${ }^{26}$

Ambedkar perceived temple entry as nothing but another ploy to keep them within Hindu fold. ${ }^{27}$ The congress was under threat to lose Dalits. By this time Muslims and Christians had already made significant inroads among Dalits, and now Dalit also explored their own autonomous self-identity like Adi-Hindu organisations. In addition to this Ambedkar's leadership have exacerbated the situation for dominant political parties like congress. Dalit were said to have pelted Hindu reformers with stones after being empowered by Adi-Hindu. ${ }^{28}$

Fears of Hindus as a "dying race" became a major political threat to Hindu nationalism after $1932 .{ }^{29}$ In democratic politics, the loss of Dalits, who constitute more than a fifth of the Hindu population, was unavoidable. The Harijan Movement should be seen as an effort to avert this political defeat. ${ }^{30}$ 
Temple Entry Movement led by Harijan Sangh yielded some positive results and at certain places of Delhi Valmiki temples were constructed. Interestingly, Chuhras were still not allowed in the corridors of the upper caste Hindu temples but were supported in establishing their own temple of Hindu cult of Valmiki. Deity or the cult was superimposed over Dalits through constant efforts by Hindu leaders in order to secure them within the Hindu fold. For this purpose, they wove different legends and myths and succeed to manipulate Dalits religious past and beliefs. They proved their already worshiped deity like Bala Shah Nuri identical to Valmiki, a Hindu cult. Consequently, decoding the origin of this cult become complex, if one tried to discover the reality, he would encounter historical facts but legends and myths. These legends would bring, so many Valmiki's to you, which would cause further confusion in equating it with Dalit religious culture.

Many of the orthodox Hindus discard the idea of temple entry for Dalit and stood against it. Several bills were proposed and circulated by the Harijan Sevak committee in order to get signatures in favour of Dalits' admission to Hindu temples, but the responses were overwhelmingly negative, and leaders eventually withdrew them. ${ }^{31}$ Several educated and elite Hindus opposed the movement, and they did not hesitate to legitimise untouchability with low caste people, while denying them access to temples. And many of them used their pen to claim that criticise those socio-religious reformers, who protested and struggled to let untouchables inside the temple. For example, Basanta Kumar Chattergi wrote an article in Indian Review 1934 titled "Temple Entry Bill" in which he stated that Hindus not only excludes untouchables to enter temples, but they also follow the same rules against Muslims and Christians. He says;

"In that case If it is highly offensive to low-caste people to be, considered as untouchable, it will be equally offensive to Christians and Mahomedans to be considered as untouchable. But no legislation is proposed to prevent orthodox Hindus from considering Mahomedans and Christians as untouchables. The reason is that any person or group of persons has the right to consider any other person or group of persons as untouchable. You may call it superstitious or foolish. But you cannot call it illegal." 32

Mr. T. G. Rama Iyer, a district officer in Mysore, strongly opposed a resolution recommending the opening of Muzrai temples to all "Untouchables." He argued that such temple entry resolutions had little value in a society where the majority still opposed granting Dalits civic rights such as marriage processions through village streets and accessing water from common village wells. He said that Dalits themselves were not interested in temple entry and would be unable to accept it. Mr. S. P. Rajagopalachari also argued that, though the government sympathised with Dalit aspirations, but it bore responsibility for both Dalits and Hindus. Thereby, should not risk to hurt upper caste while addressing the aspiration of Dalits. It could not impose temple entry resolution over upper caste Hindus especially when public opinion did not like to endorse it. Before imposing anything like Government must first win or educate the public opinion. ${ }^{33}$

According to reports, Chamars were permitted to enter temples up to a certain distance if they wore wet loincloths (dhotis), while other untouchable castes such as the Bhangi were completely barred from doing so. ${ }^{34}$ Ambedkar notified that the temples are closed to low caste with hanging boards on the Hindu temples particularly saying: "All Hindus and all animals including dogs are admitted, only Untouchables not admitted". ${ }^{35}$ Even after Gandhi's robust campaign the Bombay Provincial Board of the Servants of Untouchables Society reports that only 20 temples were available for Dalits. ${ }^{36}$ Gradually, it's found that municipal and health officials began to advocate for the construction of a Valmiki temple for their sanitation workers. On the 26th of July 1933, at Khasra Nos. 2536/2539 of Basti Rahgar, about 200 square yards of land worth Rs. 200 was approved to build a Valmiki temple. ${ }^{37}$ Another allotment of 426 sq yards, included plot 70-71 of 
value Rs. 300 was also made for a Valmiki temple at Naiwala. ${ }^{38}$ Delhi Improvement trust provided a land of 204.38 square allotted to Balmiki Sabha of Dariyaganj for Valmiki temple. ${ }^{39}$ However, at the time of the approval and allotment of land the government's prime concern was to escape the possibility of any communal clashes. The presence of the Valmiki temple in this region could lead to a conflict between Mehtar and Hindus, as well as Mehtar and Muslims. To avoid this, the government agreed to provide them with land on the southern side of the plane via the Basti Ara Kashan Scheme. ${ }^{40}$ On the similar ground Chamar temple also became a matter of concern because its proximity to Mata Sundri Gurdwara office ${ }^{41}$ Another application of requesting land grant for the construction of temple on the same excuse that was its close proximity to the Mosque at one side and cemetery on the other side, Malka ganj. ${ }^{42}$ Besides these references, there are examples of Dalits being granted land to build their own temples dedicated to Gods and Goddesses worshipped by upper castes. In 1940, the Dalits of Basti Harpool were given 194.452 yards of land to build a Shiva temple. ${ }^{43}$ All of these lands were given to temple builders for free, but sweepers were compelled and ordered to use them only for temple building. ${ }^{44}$ In an interview with the city magistrate, Mr. Ganpat, President of Mehtar Union, says

"while the allotment of the site will be welcome, there is much disappointment at the restriction proposed to be imposed on the use of the site for the temple only. It is pointed out that on the original site it was proposed to erect shops and flats and to reserve some accommodation for a school. The object of the former was to make the temple selfsupporting. As you are aware, many religious institutions and buildings rely for maintenance upon such rents. Provided the shops and tents are properly maintained, I see no objection particularly in the case of a temple serving needs of a poor community such as the sweepers........It would be essential of course for the plans of such buildings to be duly approved by the Chairman of the Delhi Improvement trust and to be maintained in good order" ${ }^{\prime 4}$

Despite the fact that the Valmiki cult now occupies almost all public spaces, it has not been able to eliminate Lal Beg's presence. Lal Beg, like other deities such as Sitala Mata, lives in people's memories, and continue to occupy a space in oral beliefs, and domestic spaces. ${ }^{46}$

Here the role of Amin Chand become significant, one of the Gandhian Dalit leaders, played a key role in the establishment of the Valmiki cult in Chuhra culture. His involvement in the 1935 scavengers strike, as well as his six-and-a-half-month imprisonment, earned him Chuhras' confidence.

Chennu Devi of the Kanya, Mahavidyalaya, Hans Raj, and Sadhu Yodhnath all joined him within a year to bring the Chuhras into the Hindu fold. The importance of Bhajans and Kathas were recognised, prompting Sadhu Yodhnath to compose hymns and songs for the purpose of bringing Rishi Valmikes to Chuhras, and Amin Chand to write the Valmiki Prakash in 1936, which became the standard Chuhra tract. Bhajans were important in the Arya Samajist movement because so much of their activism and politics revolved around the worship of Rishi.

In 1936 G.D Birla urged Thakar Bapa (leader of Harijan Sewak Sangh) to adopt a similar path to avoid the loss of Dalits from Hindu fold as they were found ceaselessly converting into other religions and thereby abounding Hinduism. He ordered to raise the expenditure on composition of Bhajans and Kathas. In 1936, Amin Chand wrote Valmiki Prakash, which became the Chuhras' standard tract. He imitated Dayanad's Sarswati and wrote a text similar to "Satyarth Prakash." ${ }^{47}$ He composed a doctrine against the adversaries of faith in the Valmiki cult. His Balmiki Prakash, Balmiki Darshan and Balmiki Sandesh soon became the prominent text on Valmiki cult. ${ }^{48}$ Balmikis Prakash narrates a conversation between a Ram Sevak and a Balmiki man. Here Ram Sevak is at his temple reading Ramayna. When he takes the name of Valmiki in a verse (shlok), a Valmiki man sweeping the street on listing this, asks Ram Sevak a series of questions over Valmiki. ${ }^{49}$ 
This fictitious conversation between a Ram Sevak and a Valmiki man involves praise for Valmiki as well as an assault on low caste movements as false religions with no saint or scripture. It further divides Chuhras and Hindus, much as it does Muslims and Christians. A question was raised about Valmiki's position, specifically whether Chuhras should regard him as an ancestor or a guru (teacher). The man as informed that Valmiki was a Chuhras preceptor. ${ }^{50}$ Another question he raised was whether Hindu text, Ramayana, was written by a low caste, or the Valmikis are not low castes. On the question of ancestry of Valmiki, Ram Sevak claims that he was a Brahmin and a Shudra. ${ }^{51}$ If Vamliki is not his ancestor, why does he need to revere him, the sweeper asks again. Ram Sevak replies Brahmins do not encourage low caste people to read Vedas, but Valmiki's writings can be read and held by everyone, from Brahmins to low caste people. Sweeper man again asks, "If guru is so important, why don't we just revere Lal Beg?" Ram Sevak responds that Lal Beg is a Valmiki disciple. He went on to say that everyone who introduces themselves as Lalbegi is wrong, and he demanded angrily that he recognise himself as a Valmiki. ${ }^{52}$ Amin Chand's writings also elaborated upon rituals to prove Chuhra association to Hinduism..$^{53}$

These campaigns convinced Lalbegis that Lal Beg was a corruption of Lal beg (the red monk), and he accepted him as a Valmiki devotee. Nicolas Jaoul argues that by accepting the Valmiki cult Chuhras tried to negotiate for the patronage in elite politics and therefore, it should not be seen as an abject surrender of their own identity ${ }^{54}$ At many places Lalbegi places of worship were replaced with Valmiki temples and Chuhras recognized him as their mythological teacher. Thus, Hindu reformist succeeded in altering original sect and religious traditions of sweeper, who caught between political forces of emancipation and patronage. ${ }^{55}$

As in the representational politics Dalits played a decisive factor in deciding whether India is a Hindu majority or not, Government found another way to compel them to recognized themselves as Hindu. ${ }^{56}$ It was through the Government policies, according to which only those Dalits could avail reservation who profess Hindu religion. Lalbegi and Mehtars were excluded from such benefit simply because of possessing Muslims names and worshiping Lal Beg and Sharines. Joel also mentions that preachers were sent to Dalit's localities to recast their historical memories, culture, and live style into Hindu one. He says that even marriages become crucial sites of the tussle between the traditional leadership and reformists. All must be determined and put into effect, including the rituals to follow, what to prepare and serve, and whether Fatiha (Quranic prayer) should be included in the ceremony. In fact, conflicts were sparked over the use of utensils, Hindu reformists through their rallies urged (or imposed) the use of bhegauna (vessel) over Valmikies to replace dags the vessel that for some complex reasons represent the Muslims. Though, they partially succeed over it on a pretext that the reformist and Congress will not come and eat in Dalits functions if they make their food in degchi, but they could not win the conflict absolutely as this is the non-veg meal cooked in bhagauna rather than the veg-one. ${ }^{57}$ Thus customs performed at weddings, food cooked, or utensils used, all aided in marking the identity of Valmikis distinct from Lalbegis.

\section{CONCLUSIONS}

The Harijan Sevak Sangh campaigns utterly failed to earn success in eradicating untouchability from Hindu society. Dalits' socio-economic and political standing remained unchanged, but it did help the Congress to build a strong Dalit support for itself. When the Civil Disobedience Movement was on the verge of collapsing, the Harijan movement, thanks to its electoral victory in 1937, became a vibrant force in gaining widespread support and volunteer groups for Quit India Movement. Though, its campaign recorded limited success for the Harijans. ${ }^{58}$ However, some researchers argue in favour of the Congress' paternalistic approach, claiming that Gandhi, who had a wider following among India's masses, utilised 
his power to uplift Dalits. ${ }^{59}$ Gandhi's views, which were based on a paternalistic approach to issues of caste and untouchability, were more widely accepted than radical Dalit notions like Ambedkar's, which focused more on political and economic empowerment. ${ }^{60}$ Gandhi and the congress finally won to set a tactical adjustment with radical Dalit leadership, make them bow down and come near to them politically, though not ideologically before independence. ${ }^{61}$

'Declarations of interest: none'.

\section{SUBMISSION DECLARATION AND VERIFICATION AND ACKNOWLEDGEMENT}

Here I declare that I am the sole author of this manuscript. This paper is not under consideration for publication elsewhere. I also promised that if this paper accepted, it will not be published elsewhere in the same form, in English or in any other language, including electronically without the written consent of the copyright holder. I am thankful to the ICSSR (Indian Council of Social Science Research) for providing me Centrally administered Doctoral fellowship, to support my research.

\section{REFERENCES}

1. ${ }^{1}$ Rama Sharma, Bhangi, Scavenger in Indian Society: Marginality, Identity and Politicization of the Community, New Delhi: M. D. Publications, Ltd, 1995.p.160.

2. $\quad{ }^{2} I b i d .$, p. 147.

3. ${ }^{3}$ Jayeeta Sharma, Work, Temple and Identity: A Balmiki Neighbourhood in New Delhi, Department of History, University of Delhi. December, 1996.p.44; Harish K.Puri, Paramjit S. Judge (eds), Social and Political Movements: Readings on Punjab, Jaipur: Rawat, 2000.p.221; Rama Sharma, Op. Cit.p.147.

4. $\quad{ }^{4}$ A. K. Vakil, Gandhi Ambedkar Dispute, (New Delhi: Ashish Pub. House, 1991), p.27.

5. ${ }^{5}$ A. K. Vakil, Gandhi Ambedkar Dispute, (New Delhi: Ashish Pub. House, 1991), p.27. Christophe Jaffrelot, Dr Ambedkar and untouchability: Analysing and fighting caste. New Delhi: Permanent Black, 2005.

6. ${ }^{6}$ Vijay, Prashad, The killing of Bala Shah and the birth of Valmiki: Hinduisation and the politics of religion. Indian Economic and Social History Review 32, (1995), p.304.

7. ${ }^{7}$ Ibid., pp.306-307.

8. $\quad 8$ Arokiaswami, "The Birth of the Harijan Movement," Op. Cit., p.176; S. K Chahal, Dalits patronised: the Indian national congress and Untouchables of India 1921-1947. New Delhi: Shubhi Publications, 2002.p.14.

9. $\quad{ }^{9}$ Vijay, Prashad, The killing of Bala Shah and the birth of Valmiki, Op. Cit., p,304.

10. ${ }^{10}$ Ibid., 306-307.

11. ${ }^{11}$ Arokiaswami, Op. Cit., p.176; Vijay, Prashad, Op. Cit., pp.306-307.

12. ${ }^{12}$ Arokiaswami, Op. Cit., 176.

13. 13 “work of Harijan Sevak Sangh: No Adjunct of Congress”, TOI, 22 July, 1938.

14. ${ }^{14}$ Ibid.

15. 15 "Full-time Workers for Harijan Cause: Sevak Sangh adopts Gandhi Scheme”, TOI, 18 May 1938.

16. ${ }^{16}$ Arokiaswami, "Op. Cit., p.175. 
17. ${ }^{17}$ Vijay, Prashad, The killing of Bala Shah and the birth of Valmiki, Op. Cit.p.308.

18. ${ }^{18}$ Bipan Chandra, Mrdula Mukherjee, Aditya Mukherjee, Sucheta Mahajan, K.N.Panikkar, India's Struggle for Independence (1857-1947), Penguin Books, New Delhi1989, p.295.

19. ${ }^{19}$ Jayeeta Sharma, Op. Cit., pp.46-47; 15-16.

20. ${ }^{20}$ Ibid., pp.46-47.

21. ${ }^{21}$ Ibid., pp.46-47.

22. 22 "Harijan Uplift: Tour of Secretary of all India Society a correspondent”, TOI, 23 August 1933.

23. ${ }^{23}$ Uma Prasad Thapliyal, Gazetteer of Rural Delhi, Gazetteer Unit, Delhi Administration, Delhi, 2000. p.313.

24. 24 "Untouchables to be Admitted into Temple: A Delhi Gesture, Times of India, 15 September, 1932.

25. 25 "Harijans Challenge to Hinduism Mr. Gandhi on their Rights, " TOI, 3 June 1936.

26. 26 “Dr.Ambedkar's New Demand: Abolition of Caste, Temple Entry not Good Enough; Mr.Gandhi Attitude”, TOI, 6 Feb 1933; "Harijan Uplift", TOI, 8 Jun1933.

27. ${ }^{27}$ Arokiaswami, "The Birth of the Harijan Movement, "Op. Cit., p.183.

28. ${ }^{28}$ Vijay, Prashad, The killing of Bala Shah and the birth of Valmiki, Op. Cit.pp.308-309.

29. ${ }^{29}$ Jayeeta Sharma, Op. Cit., pp.42, 43-44.

30. ${ }^{30}$ Arokiaswami, "The Birth of the Harijan Movement, "Op. Cit., p.183.

31. ${ }^{31}$ Ibid., p. 179 .

32. ${ }^{32}$ Basanta Chatterji, 'The Temple Entry Bill' Indian Review: G.A. Natesan \& Co. 1934.p.516.

33. 33 "State Temples and Untouchables: Legislation Difficulty", The Times of India, 30 January,1937.

34. ${ }^{34}$ E.A.H Blunt,. The Caste System of Northen India: with special reference to the United Province of Agra and Qudh, S. Chand and co, Delhi, 1969. p.4.

35. ${ }^{35}$ Ambedkar, B. R. What Congress and Gandhi have done to the Untouchables? New Delhi, (1945) 2009.p.107.

36. ${ }^{36}$ Harijan Uplift, Op. Cit.,

37. ${ }^{37}$ Grant of land in Basti Reghar for the Construction of a Temple for the use of Sweeper, 1933 file no. 89, DSA.

38. ${ }^{38}$ Grant of Land in Qarol Bagh to the Hindu Residents for the Construction of a Temple, 1934, file no 4(68). DSA.

39. ${ }^{39}$ Lease of Land in Daryaganj free of Rent by the Delhi Improvement Trust of the Balmiki Sabha for the purposes of a Temple, 1940, file no 1(69) DSA.

40. ${ }^{40}$ Cost of Development of a Site allotted to the Mehtar Union for the Construction of a Balmiki Temple Chief Commissioner, 1943, File no. 1(70), DSA.

41. ${ }^{41}$ Construction of a Chamars Temple near the Mata Sundri Gurdwara, 1937, file no.70, DSA.

42. ${ }^{42}$ Lease by the Notified Area Committee, Civil Station, Delhi to the Mehtar Labour Union, Delhi, of Land for the Construction of a Temple, 1939, file no 4(79).

43. ${ }^{43}$ Proposed Transfer of Land at Basti Harphool Singh to the Depressed Classes Shiv Temple Committee, 1940, fie no 2(104). 
DSA.

44. ${ }^{44}$ Allotment of Land belonging to the Delhi Improvement Trust in Mohamedans to the Mehtar, 1941, file no. 1 (100).DSA; Grant of Land in Qarol Bagh to the Hindu Residents, Op. Cit.,;Grant of land in Basti Rahgar Op. Cit.,; Allotment of Land belonging to the Delhi Improvement Trust in Mohamedans to the Mehta Chief Commissioner 1937; Lease of Land in Daryaganj Op. Cit.; Allotment of Land belonging to the Delhi Improvement Trust in Mohamedans to the Mehta Chief Commissioner 1941

45. ${ }^{45}$ Allotment of Land belonging to the Delhi Improvement Trust in Mohamedans, Op. Cit.,

46. ${ }^{46}$ Jayeeta Sharma, Op. Cit., p.27.

47. ${ }^{47}$ Jayeeta Sharma, Op. Cit., pp.25-26.

48. ${ }^{48}$ Ibid., pp.25-26.

49. ${ }^{49}$ Vijay, Prashad, The killing of Bala Shah and the birth of Valmiki, Op. Cit.pp.308-309.

50. ${ }^{50}$ Jayeeta Sharma, Op. Cit., pp.26-27, Vijay, Prashad, The killing of Bala Shah and the birth of Valmiki, Op. Cit., pp.309-310.

51. ${ }^{51}$ Vijay, Prashad, The killing of Bala Shah and the birth of Valmiki, Op. Cit.pp.309-310.

52. ${ }^{52}$ Ibid., p.311-312. Vijay Prashad, Untouchable Freedom, Op. Cit. P 98. Rama Sharam Op. Cit., p.137.

53. ${ }^{53}$ Jayeeta Sharma, Op. Cit., p.26-27, Vijay, Prashad, The killing of Bala Shah and the birth of Valmiki, Op. Cit.pp.309-310.

54. ${ }^{54}$ Nicolas Jaoul (2011) Casting the 'sweepers'. Local politics of sanskritisation, caste and labour. In: Berti D, Jaoul N and Kanungo P (eds) Cultural Entrenchment of Hindutva: Local Mediations and Forms of Convergence. New Delhi: Routledge, p.278.

55. ${ }^{55}$ Ibid., $p 278$.

56. ${ }^{56}$ Joel Lee'Jagdish, Son of Ahmad: Dalit Religion and Nominative Politics in Lucknow', South Asia Multidisciplinary Academic Journal11 | 2015pp2-3.DOI: 10.4000/samaj.3919

57. ${ }^{57}$ Ibid., p.11.

58. ${ }^{58}$ S. K Chahal, Op. Cit. p.14

59. ${ }^{59}$ Ibid., p. 14 .

60. ${ }^{60}$ Ibid., p. 14.

61. ${ }^{61}$ Ibid., p.15.

62. Singh, Mamta, and Rajendra Singh. "Art And Architectureof Jain Temples In Uttar Pradesh, India." Nanoscale Research Letters 7: 584.

63. JHA, BISHNU M., and A. Mandal. "Overcut and Profile of the Machined Features in Electrochemical Machining." IASET: International Journal of Metallurgical, Materials and Chemical Engineering (IASET: IJMMCE) 1 : 29-40.

64. Sharanabasappa Saddu, Sangshetty Kivade \& S. V. Khandal, "The Comparison of used Temple Oil Biodiesel Productivities with the Other Biodiesel”, International Journal of Mechanical and Production Engineering Research and Development (IJMPERD) , Vol. 8 Issue 5, pp, 437-448

65. Shobha Shouche \& Satyendra Singh Ratnakar, "Butterfly Fauna in Four Sites of Ujjain City, Madhya Pradesh, India", International Journal of Biological Research and Development (IJBRD) , Vol. 5, Issue 2, pp, 1-4 